\title{
Densification behavior of yttria-stabilized zirconia powders for solid oxide fuel cell electrolytes
}

\author{
Dhruba PANTHI ${ }^{a, b}$, Nader HEDAYAT ${ }^{a}$, Yanhai DU $^{a,{ }^{*}}$ \\ ${ }^{a}$ College of Aeronautics and Engineering, Kent State University, \\ 1400 Lefton Esplanade, Kent, Ohio 44242, USA \\ ${ }^{b}$ Department of Engineering Technology, Kent State University at Tuscarawas, \\ 330 University Dr NE, New Philadelphia, Ohio 44663, USA
}

Received: December 25, 2017; Revised: April 29, 2018; Accepted: May 9, 2018

(C) The Author(s) 2018. This article is published with open access at Springerlink.com

\begin{abstract}
Yttria-stabilized zirconia (YSZ) is the most common electrolyte material for solid oxide fuel cells. Herein, we conducted a comparative study on the densification behavior of three different kinds of commercial 8 mol\% YSZ powders: (i) TZ-8Y (Tosoh, Japan), (ii) MELox 8Y (MEL Chemicals, UK), and (iii) YSZ-HT (Huatsing Power, China). The comparison was made on both the selfsupporting pellets and thin-film electrolytes coated onto a NiO-YSZ anode support. For the pellets, MELox 8Y showed the highest densification at lower sintering temperatures with $93 \%$ and $96 \%$ of the theoretical density at 1250 and $1300{ }^{\circ} \mathrm{C}$, respectively. Although YSZ-HT showed a higher sintering rate than TZ-8Y, a sintering temperature of $1350{ }^{\circ} \mathrm{C}$ was required for both the powders to reach $95 \%$ of the theoretical density. For the thin-film electrolytes, on the other hand, YSZ-HT showed the highest sintering rate with a dense microstructure at a co-sintering temperature of $1250{ }^{\circ} \mathrm{C}$. Our results indicate that besides the average particle size, other factors such as particle size distribution and post-processing play a significant role in determining the sintering rate and densification behavior of the YSZ powders. Additionally, a close match in the sintering shrinkage of the electrolyte and anode support is important for facilitating the densification of the thin-film electrolytes.
\end{abstract}

Keywords: yttria-stabilized zirconia (YSZ); SOFC electrolyte; densification; shrinkage; co-sintering

\section{Introduction}

Solid oxide fuel cells (SOFCs) are regarded as attractive power generation devices for various applications because of their high efficiency, low emissions, and flexible operation on hydrogen and hydrocarbon fuels [1-3]. Yttria-stabilized zirconia (YSZ) is the most widely used electrolyte material for SOFCs along with other solid-state electrochemical

* Corresponding author.

E-mail: ydu5@kent.edu cells such as solid oxide electrolysis cells (SOECs) and oxygen gas sensors. YSZ is known for its high ionic conductivity owing to the increased mobility of oxygen vacancies at elevated temperatures [3,4]. Moreover, YSZ shows excellent stability in both reducing and oxidizing atmospheres. Compared with other SOFC electrolyte materials, YSZ offers competitive advantages from the viewpoints of cost and availability of highquality raw materials [5]. YSZ also possesses high fracture toughness and mechanical strength [6], thus making it suitable for a self-supporting electrolyte. Although electrolyte-supported designs were common 
for high-temperature SOFCs, the ohmic loss associated with ionic conduction through the thick electrolyte was a main barrier to reducing the SOFC operating temperature to an intermediate range $\left(600-800{ }^{\circ} \mathrm{C}\right)$. As a result, electrode-supported SOFCs with a thin-film electrolyte have recently been in common use.

For the production of electrode-supported SOFCs, the electrolyte is usually co-sintered with the support electrode at temperatures $\geqslant 1400{ }^{\circ} \mathrm{C}$ to get a fully densified microstructure [7-9]. Owing to the fact that sintering temperature of SOFC electrodes is only between 1150 and $1250{ }^{\circ} \mathrm{C}$, decreasing the electrolyte sintering temperature to this range would result in lower sintering costs and shorter production cycle time. Additionally, the low-temperature sintering of the electrolyte offers further advantages including the prevention of microstructure coarsening of the electrode and suppression of undesirable reactions between the electrolyte and electrode materials [1013]. Since conventional multi-step sintering of the SOFC components involves significant time and energy [14], single-step co-firing techniques have recently been proposed $[15,16]$. However, lowering the electrolyte sintering temperature to below $1300{ }^{\circ} \mathrm{C}$ has been one of the major challenges for successful realization of the single-step co-fired SOFCs. The low-temperature sintering of the electrolyte is also important for inert substrate-supported SOFCs [17-19] and metalsupported SOFCs [20-22]. For the inert substratesupported SOFCs, lower sintering temperature is desirable to maintain an acceptable porosity in the inert support. Likewise, the electrolyte sintering at lower temperatures reduces species diffusion and reactivity between the metal substrate and other cell components in the metal-supported SOFCs.

In recent years, researchers have employed different approaches to lower the electrolyte sintering temperature. For example, the reduction of YSZ particle size to nano-scale was helpful in achieving a dense electrolyte microstructure at sintering temperatures as low as $1000{ }^{\circ} \mathrm{C}$ [23]. However, rapid grain growth of the YSZ nano-particles leading to inhomogeneous microstructure and $\mathrm{Y}_{2} \mathrm{O}_{3}$ segregation at elevated temperatures have been found to be critical issues [24]. Low-temperature densification of SOFC electrolytes by adding small amounts of sintering aids has also been widely reported [25-28]. Despite promising results from some sintering aids, the effect of sintering aids on the ionic conductivity and long-term stability of the electrolyte has been a concern. Another approach to lowering the electrolyte sintering temperature is using novel sintering techniques such as spark plasma sintering (SPS) [29,30]. The SPS technique enables rapid densification of ceramic materials at relatively low temperatures due to the fast heating rates provided by a pulsed DC current under applied pressure. However, this technique is still under development and requires an expensive setup. Considering these facts, further studies are imperative to achieve low-temperature densification of the YSZ electrolyte using cost-effective techniques and without compromising its ionic conductivity and stability.

It is notable that the synthesis routes and characteristics of the commercially available YSZ powders vary considerably. A thorough understanding of the densification behavior of the different YSZ powders would help to optimize their sintering profile and bring down the sintering temperature. In the present work, we selected three different types of commercially available $8 \mathrm{~mol} \% \mathrm{YSZ}$ powders and compared their sintering and densification behavior. The YSZ powders were synthesized using three different routes, and their particle sizes ranged from nanometer to sub-micron scales. Most of the sintering studies reported in the literature for SOFC electrolytes were conducted in self-supporting electrolyte pellets. These studies may not represent the densification behavior of the state-ofthe-art thin-film electrolytes because additional factors such as green density of the electrolyte coating and sintering properties of the support layer play an important role [31-35]. For this reason, we compared the densification of the YSZ powders in both the pellets and thin films coated onto an anode support.

\section{Experimental}

Three commercial $8 \mathrm{~mol} \% \mathrm{YSZ}$ powders-TZ-8Y, MELox 8Y, and YSZ-HT-were obtained from Tosoh (Japan), MEL Chemicals (UK), and Huatsing Power (China), respectively. The three powders had the same chemical composition. The synthesis routes and typical characteristics of the YSZ powders as provided by the manufacturers are listed in Table 1.

The YSZ powders were compacted to disc-shaped pellets with a uniaxial hydraulic press (4350.L, Carver, IN, USA). The diameter of the pellet die was $10 \mathrm{~mm}$. To prepare each pellet, $0.5 \mathrm{~g}$ YSZ powder was pressed at a pressure of $250 \mathrm{MPa}$ for $1 \mathrm{~min}$. The green pellets were sintered at different temperatures ranging 
Table 1 Synthesis methods and characteristics of the YSZ powders used in this work

\begin{tabular}{cccc}
\hline Powder & Synthesis method & Appearance & $\begin{array}{c}\text { Surface area } \\
\left(\mathrm{m}^{2} / \mathrm{g}\right)\end{array}$ \\
\hline TZ-8Y & Hydrolysis & Spray-dried granules & $16 \pm 3$ \\
MELox 8Y & Chemical precipitation & Spray-dried granules & 7.0 \\
YSZ-HT & Liquid-phase method & Spherical particles & - \\
\hline
\end{tabular}

from 1100 to $1400{ }^{\circ} \mathrm{C}$ in a high-temperature furnace (CF 1600, Across International, NJ, USA). The furnace temperature was ramped at $3{ }^{\circ} \mathrm{C} / \mathrm{min}$, and the samples were held at the sintering temperature for $3 \mathrm{~h}$. The density of the sintered YSZ pellets was determined by the Archimedes method using deionized water as the immersion medium. The linear shrinkage of the YSZ powders was measured with a dilatometer $(1600 \mathrm{D}$, Orton, OH, USA). A standard test method for the linear thermal expansion of solid materials with a push-rod dilatometer (ASTM-E228) was followed for these measurements.

To obtain the thin-film electrolytes, slurries of the respective YSZ powders were coated onto tubular anode supports. The anode supports containing $60 \mathrm{wt} \%$ $\mathrm{NiO}$ and $40 \mathrm{wt} \%$ YSZ were pre-sintered at $1000{ }^{\circ} \mathrm{C}$ before applying the electrolyte layer. All three electrolyte slurries were prepared using the same recipe. First, the YSZ powders were dispersed in a binary solvent of toluene and ethanol with a dispersing agent (Hypermer KD-1, Tape Casting Warehouse, PA, USA). The mixture was ball milled for $4 \mathrm{~h}$ in a polyethylene container with zirconia grinding media. Then, polyvinyl butyral (PVB; B-98, Tape Casting Warehouse) and dioctyl phthalate (DOP; Sigma Aldrich, MO, USA) were added to the mixture as binder and plasticizer, respectively. The mixture was further ball milled for $24 \mathrm{~h}$ to obtain a homogeneous electrolyte slurry. The electrolyte slurries were dip coated on top of the anode supports using a desktop dip coater (PTL-MM01, MTI, CA, USA). The co-sintering of the anode-electrolyte bilayers was conducted using the same procedure as described above for the YSZ pellets.

SOFC single cell samples were also prepared to measure the open-circuit voltage (OCV) and to further confirm the gas tightness of the thin-film electrolytes sintered at lower temperatures. For these samples, a composite cathode containing $50 \mathrm{wt} \%$ strontium-doped lanthanum manganite (LSM) and $50 \mathrm{wt} \% \mathrm{YSZ}$ was dip coated onto the co-sintered half cells. In addition, a cathode current collector layer containing pure LSM was used to improve current collection from the cathode. The cathode slurries were prepared using the same solvents and organic additives as those for the electrolyte. Both the cathode layers were sintered in air at $1150{ }^{\circ} \mathrm{C}$ for $1 \mathrm{~h}$. With a cathode length of $2 \mathrm{~cm}$ and electrolyte diameter of $0.6 \mathrm{~cm}$, the active cell area was calculated to be $3.77 \mathrm{~cm}^{2}$. The electrochemical tests were conducted using a potentiostat (PGSTAT302N, Metrohm Autolab, Netherlands) equipped with a frequency response analyzer (FRA) and 20 A current. The SOFC sample was placed inside a split-tube furnace, and the furnace temperature was ramped at $5{ }^{\circ} \mathrm{C} / \mathrm{min}$ to the testing temperature. Humidified hydrogen was fed as fuel to the anode at a flow rate of $100 \mathrm{~mL} / \mathrm{min}$, whereas the cathode was exposed to the stationary ambient air. The impedance spectra were recorded under OCV conditions by applying an AC perturbation of $10 \mathrm{mV}$ for a frequency range $100 \mathrm{kHz}-$ $10 \mathrm{mHz}$.

The scanning electron microscopy (SEM) images for the YSZ powders, sintered YSZ pellets, anodeelectrolyte bilayers, and SOFC single cells were captured with a Quanta 450 microscope (FEI, OR, USA). Prior to the SEM observation, the samples were coated with a conductive layer of gold using a sputter coater (Hummer VI-A, Anatech, VA, USA). A laser scattering particle size analyzer (LA-950V2, Horiba, Japan) was used to determine the particle size distribution of the as-received YSZ powders. To break the agglomerates and obtain a homogeneous suspension for the particle size analysis, the powders were dispersed in deionized water by ultrasonication (VibraCell CV33, Sonics and Materials, CT, USA). The phase identification of the raw powders was performed using an X-ray diffractometer (XRD; D8 Discover, Bruker, USA).

\section{Results and discussion}

The SEM images of the three YSZ powders are shown in Fig. 1. The as-received TZ-8Y and MELox 8Y powders (Figs. 1(a) and 1(b)) have spherical granules with approximate average diameters of 40 and $20 \mu \mathrm{m}$, respectively. These spherical granules contain loosely connected primary particles as shown in Figs. 1(d) and 1(e). On the other hand, the YSZ-HT powder is in the form of weak agglomerates that contain spherical 

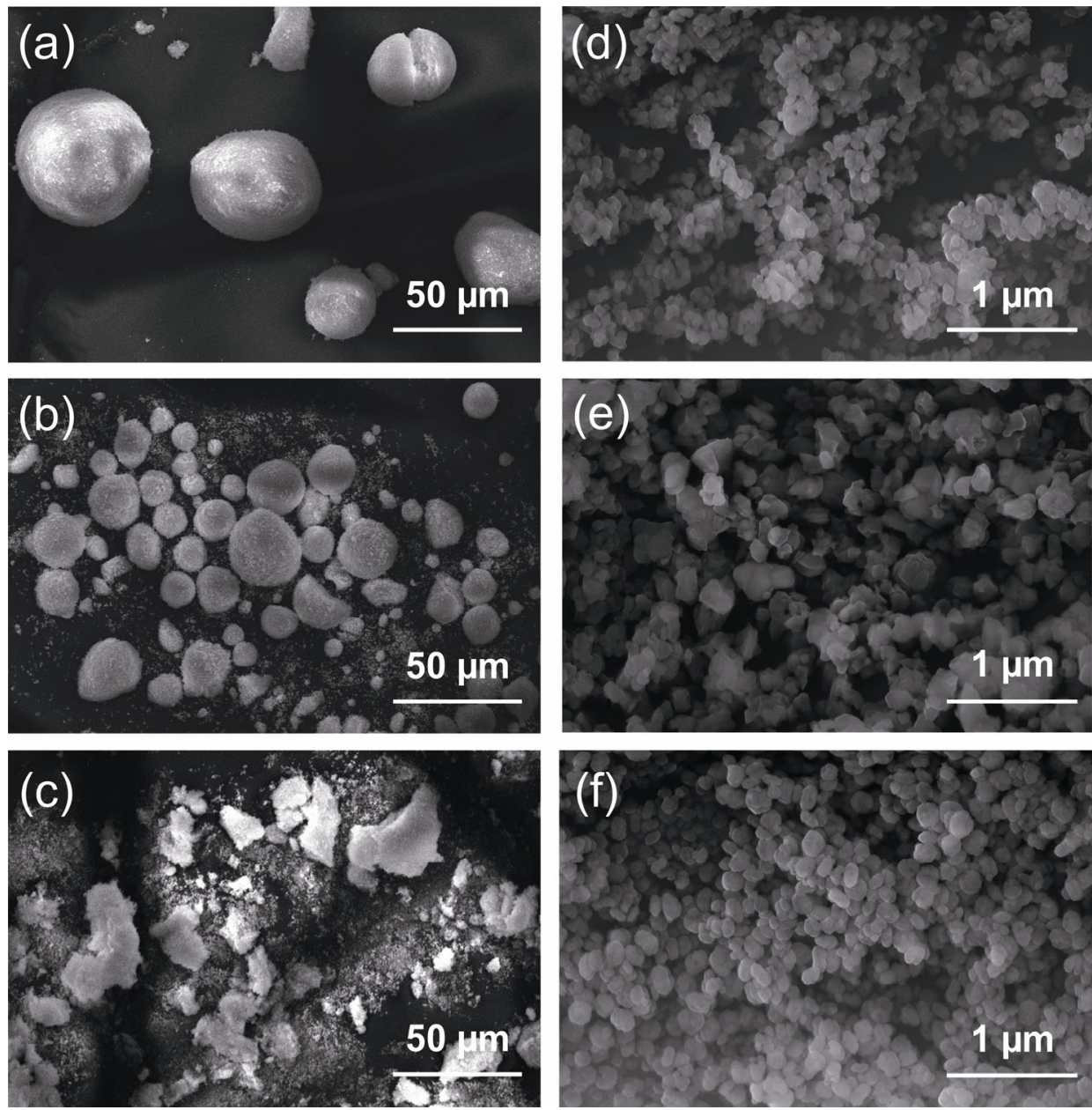

Fig. 1 SEM images of the YSZ powders: (a, d) TZ-8Y; (b, e) MELox 8Y; (c, f) YSZ-HT. The images (a-c) show the as-received form and $(\mathrm{d}-\mathrm{f})$ show the primary particles.

primary particles (Figs. 1(c) and 1(f)). As observable from the SEM images, the particle size of the MELox $8 \mathrm{Y}$ powder is relatively large, whereas the TZ-8Y and YSZ-HT powders have comparable particle sizes. Figure 2 shows the particle size distribution of the YSZ powders. The average particle sizes of the TZ-8Y, MELox 8Y, and YSZ-HT powders are determined to be 138,453 , and $81 \mathrm{~nm}$, respectively. It can be seen that the MELox $8 \mathrm{Y}$ powder has a wider particle size distribution compared with the other two kinds of powders. In particular, the YSZ-HT powder shows a very narrow particle size distribution. As shown by the cumulative frequency curve, the TZ- $8 \mathrm{Y}$ powder contains a small amount (ca. 4\%) of large particles in the range $5-10 \mu \mathrm{m}$. These particles probably represent the relatively hard agglomerates in the spray-dried powders. The XRD patterns of the YSZ powders are shown in Fig. 3. All the three kinds of powders show peaks characteristic of the cubic YSZ phase. This confirms

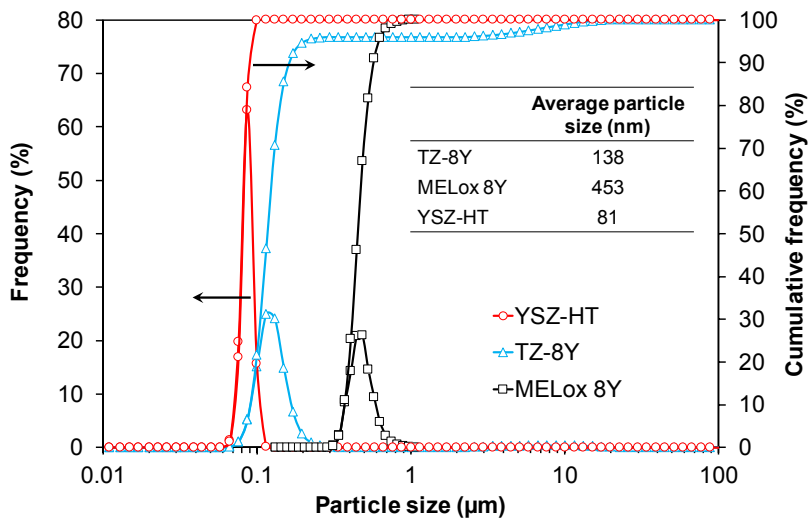

Fig. 2 Particle size distribution of the YSZ powders. The table in the inset shows average particle size $\left(d_{50}\right)$ of the powders.

that the raw powders are fully stabilized and do not contain phase impurities.

Figure 4(a) shows linear change of the YSZ compacts as a function of the sintering temperature. A 


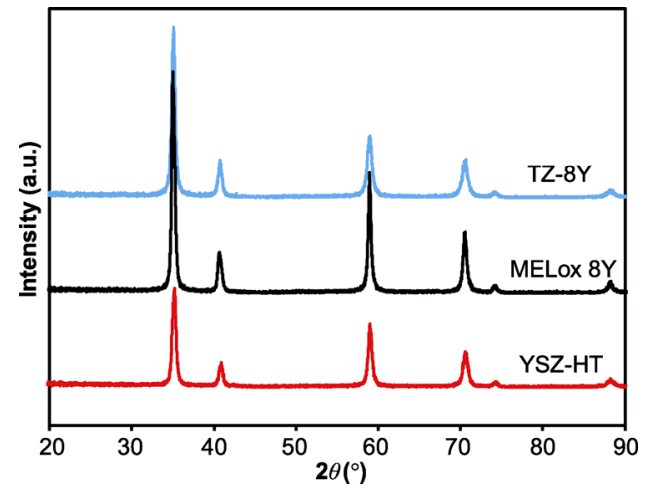

Fig. 3 XRD peaks for the YSZ powders.

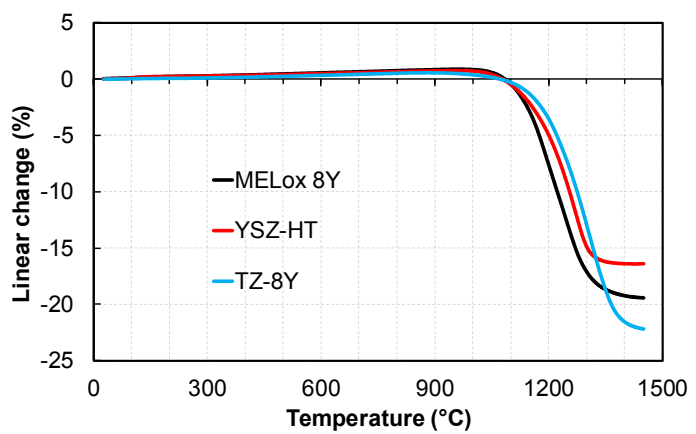

(a)

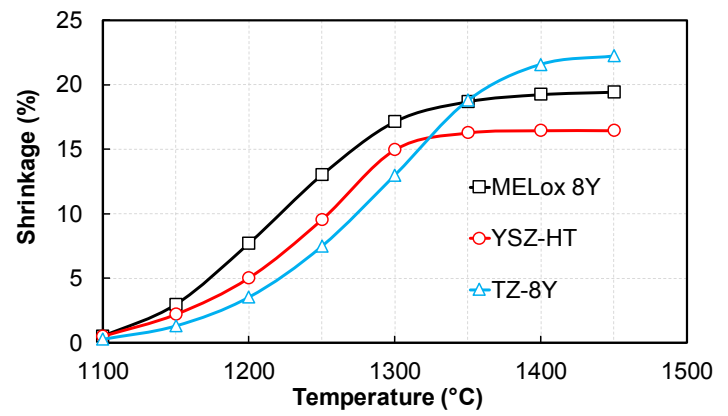

(b)

Fig. 4 Dilatometry results for the YSZ powders: (a) linear change versus sintering temperature; (b) comparison of shrinkage between 1100 and $1450{ }^{\circ} \mathrm{C}$.

magnified view of the plots to compare the shrinkage of the three kinds of powders between 1100 and 1450 ${ }^{\circ} \mathrm{C}$ is shown in Fig. 4(b). As can be seen, all the three kinds of powders have a slight increase in linear change from 600 to $950{ }^{\circ} \mathrm{C}$. This phenomenon is consistent with the reports in literature [36,37] and is likely due to thermal expansion before the sintering shrinkage started [38]. The shrinkage of all the powders starts from about $950{ }^{\circ} \mathrm{C}$. However, there is a considerable variation in the shrinkage behavior of the powders. From 1100 to $1300{ }^{\circ} \mathrm{C}$, the shrinkage is in the order of MELox 8Y > YSZ-HT > TZ-8Y. Above $1300{ }^{\circ} \mathrm{C}, \mathrm{TZ}-8 \mathrm{Y}$ shows a rapid increase in the shrinkage rate, whereas the shrinkage of YSZ-HT starts to level off. At $1350{ }^{\circ} \mathrm{C}$, both MELox $8 \mathrm{Y}$ and TZ-8Y have a shrinkage of $18 \%$. In comparison, the shrinkage of YSZ-HT is $16 \%$ at $1350{ }^{\circ} \mathrm{C}$, and this shrinkage remains nearly constant thereafter. Above $1350{ }^{\circ} \mathrm{C}$, the shrinkage is in the order of TZ-8Y > MELox $8 \mathrm{Y}>$ YSZ-HT. The maximum shrinkage achieved by MELox $8 \mathrm{Y}$ and TZ-8Y powders at $1450{ }^{\circ} \mathrm{C}$ is $19 \%$ and $22 \%$, respectively.

Figure 5(a) shows the density of the three types of YSZ pellets at different sintering temperatures. With a theoretical density of $5.9 \mathrm{~g} / \mathrm{cm}^{3}$ for the YSZ powders, the relative density of each sample is shown in Fig. 5(b). As can be seen, the density of all three kinds of powders reaches close to the theoretical density at sintering temperatures $\geqslant 1350{ }^{\circ} \mathrm{C}$. However, the MELox 8Y powder exhibits the best densification behavior at lower sintering temperatures owing to its higher shrinkage. MELox $8 \mathrm{Y}$ reaches a relative density of $93 \%$ and $96 \%$ at 1250 and $1300{ }^{\circ} \mathrm{C}$, respectively. On the other hand, the TZ- $8 \mathrm{Y}$ powder shows the lowest density at sintering temperatures below 1350 ${ }^{\circ} \mathrm{C}$. The densification behavior of the YSZ-HT powder is found to be intermediate between the MELox 8Y and TZ-8Y powders. A relative density of $\geqslant 95 \%$ is considered to be essential for a gas-tight electrolyte. A

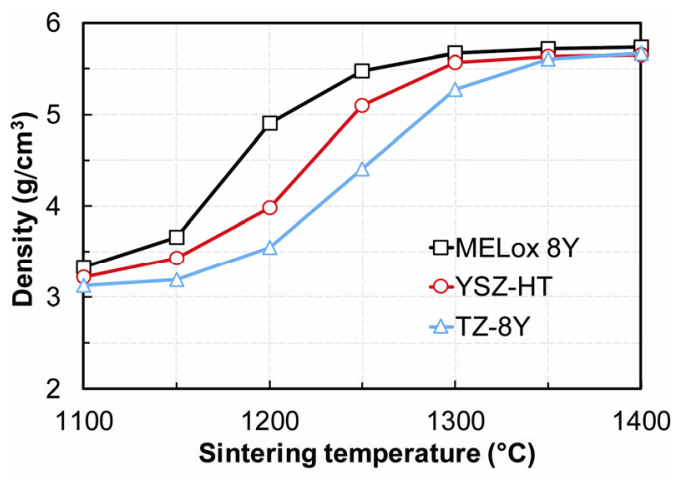

(a)

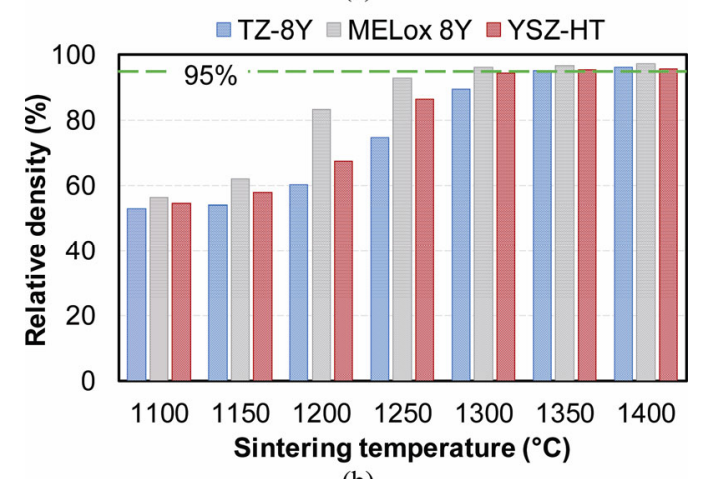

(b)

Fig. 5 (a) Density and (b) relative density of the YSZ pellets at different sintering temperatures. 
sintering temperature of $1350{ }^{\circ} \mathrm{C}$ is required for both the TZ-8Y and YSZ-HT powders to reach this relative density. It can be observed that the shrinkage rate and increase in density do not show a linear relationship over the whole temperature range. Theoretically, the density should increase in the same rate as the shrinkage because the neck growth and pore shrinkage reduce the distance between particles during sintering. However, several other factors such as connection between the pores and pore coarsening could affect the actual density of the sintered samples [39].

It is generally considered that a smaller particle size leads to better densification of the electrolyte powders owing to the higher surface energy of the fine particles. However, the superior densification of the relatively large-sized MELox 8Y powder in this work suggests that other factors besides the average particle size also play a significant role in determining the sintering rate and densification behavior. These factors possibly include the powder synthesis method, particle size distribution, and post-processing of the powders. The synthesis method determines various powder characteristics including phase purity and homogeneity of the dopant concentration. These characteristics, in turn, may influence the densification behavior. The particle size distribution is another important factor determining the shrinkage and sintered density of the ceramic powders. For comparable mean diameters, a wider grain size distribution of the YSZ particles was reported to result in a higher sintered density [40]. Additionally, post-processing of fine powders using techniques such as spray drying to form free-flowing granules helps to achieve higher density of the powder compacts [41]. As claimed by the manufacturers and also confirmed by the XRD patterns in Fig. 3, all the three YSZ powders can be considered to have a high purity and homogeneous dopant concentration. Then, taking into account a significant difference in the densification rate of the two spray dried powders (TZ-8Y and MELox 8Y), a more plausible reason for the rapid densification of the MELox $8 \mathrm{Y}$ powders is its relatively wide particle size distribution. This is also supported by the fact that the use of mixed-size particles with a wider particle size distribution was found to have a positive impact on the sintering density of the YSZ powders [31,42].

A comparison of the surface microstructure of the YSZ pellets sintered at 1250,1300 , and $1350{ }^{\circ} \mathrm{C}$ is shown in Fig. 6. At $1250{ }^{\circ} \mathrm{C}$, the MELox 8Y and TZ-8Y pellets show porous microstructures. In contrast, the
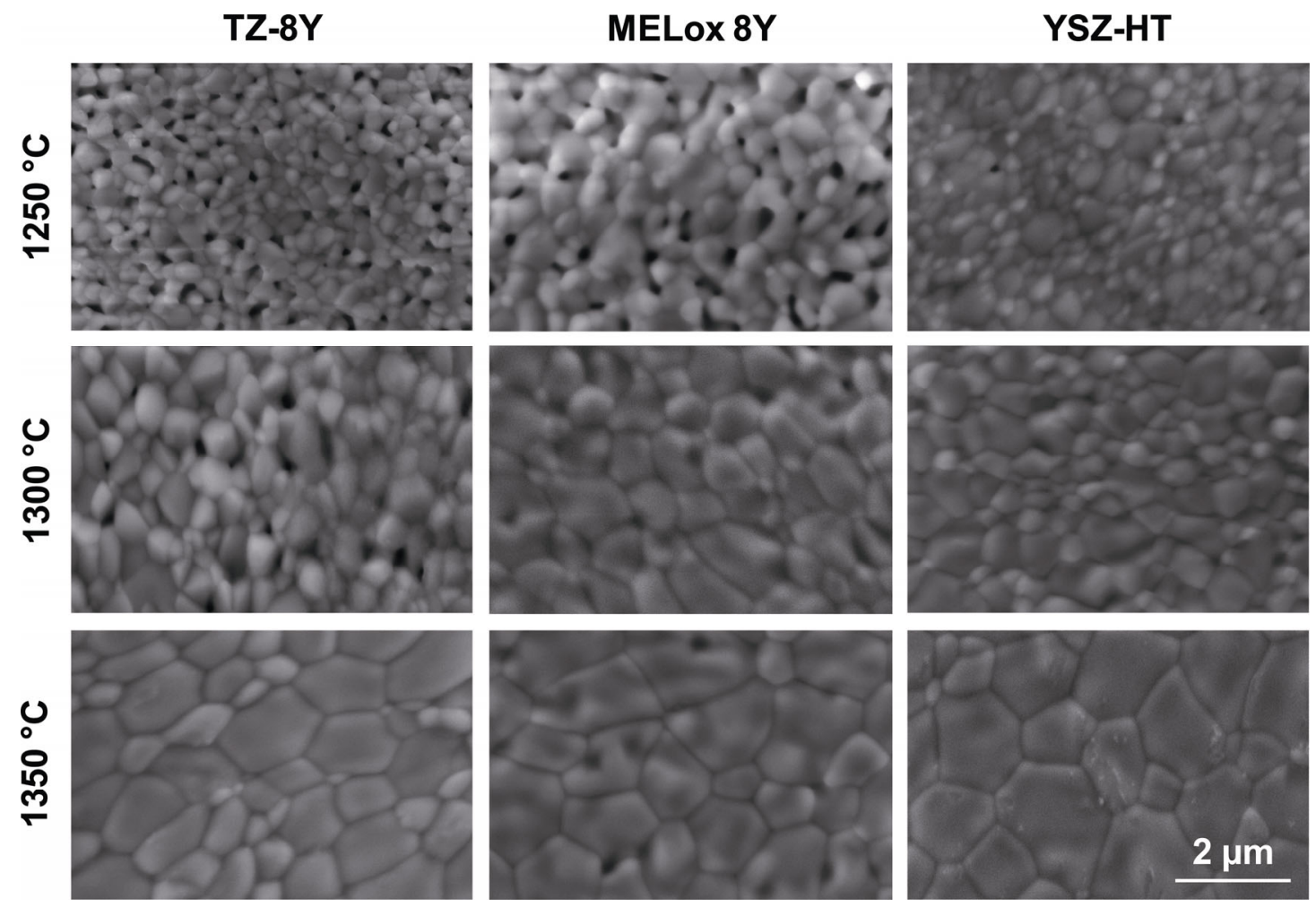

Fig. 6 SEM images showing the surface microstructure of the pellets made of different YSZ powders and sintered at different temperatures. The scale bar applies to all the images. 
YSZ-HT pellet shows a dense microstructure with very low residual porosity. This is an interesting observation considering the shrinkage and relative density of the YSZ-HT powder at $1250{ }^{\circ} \mathrm{C}$. At $1300{ }^{\circ} \mathrm{C}$, the TZ-8Y pellet still has a porous microstructure, whereas the MELox 8Y and YSZ-HT pellets exhibit full densification. At $1350{ }^{\circ} \mathrm{C}$, all the three kinds of YSZ pellets are fully dense, and their grain sizes are more or less comparable. Although the microstructures of the TZ-8Y and MELox 8Y pellets are consistent with their sintered densities, the YSZ-HT pellet shows higher sinterability than expected from the density measurements. To understand this contrasting behavior, the SEM imaging of a few samples polished with a fine sand paper was also conducted. Figure 7 shows SEM images of the polished YSZ pellets sintered at $1300{ }^{\circ} \mathrm{C}$ and thermally etched at $1250{ }^{\circ} \mathrm{C}$. These images reveal that the microstructures of the TZ-8Y and MELox 8Y pellets are homogeneous, whereas the YSZ-HT pellet has an inhomogeneous microstructure with porous regions or defects (Fig. 7(c)). Because of these defects, the density of the YSZ-HT pellet is lower, although it appears to be fully dense in the defect-free regions (Fig. 7(f)). The relatively poor mechanical strength of the sintered YSZ-HT pellets is also indicative of the defects in the microstructure. The defects in the YSZ-HT pellets are attributed to the agglomeration of fine YSZ particles. The agglomeration of very fine primary particles due to surface forces, liquid, or a solid bridge is a common phenomenon that leads to poor compaction and inhomogeneous densification during sintering [43]. Although the MELox $8 \mathrm{Y}$ and TZ-8Y powders are also in the form of agglomerates, their spherical shape results in high fluidity and good compaction [44]. In contrast, the irregular-shape agglomerates of the YSZ-HT powder have low fluidity and poor compaction. The poor compaction of the YSZHT powder leads to density gradients in the green pellets and thus an inhomogeneous sintered microstructure.

To compare the densification behavior of the thin-film
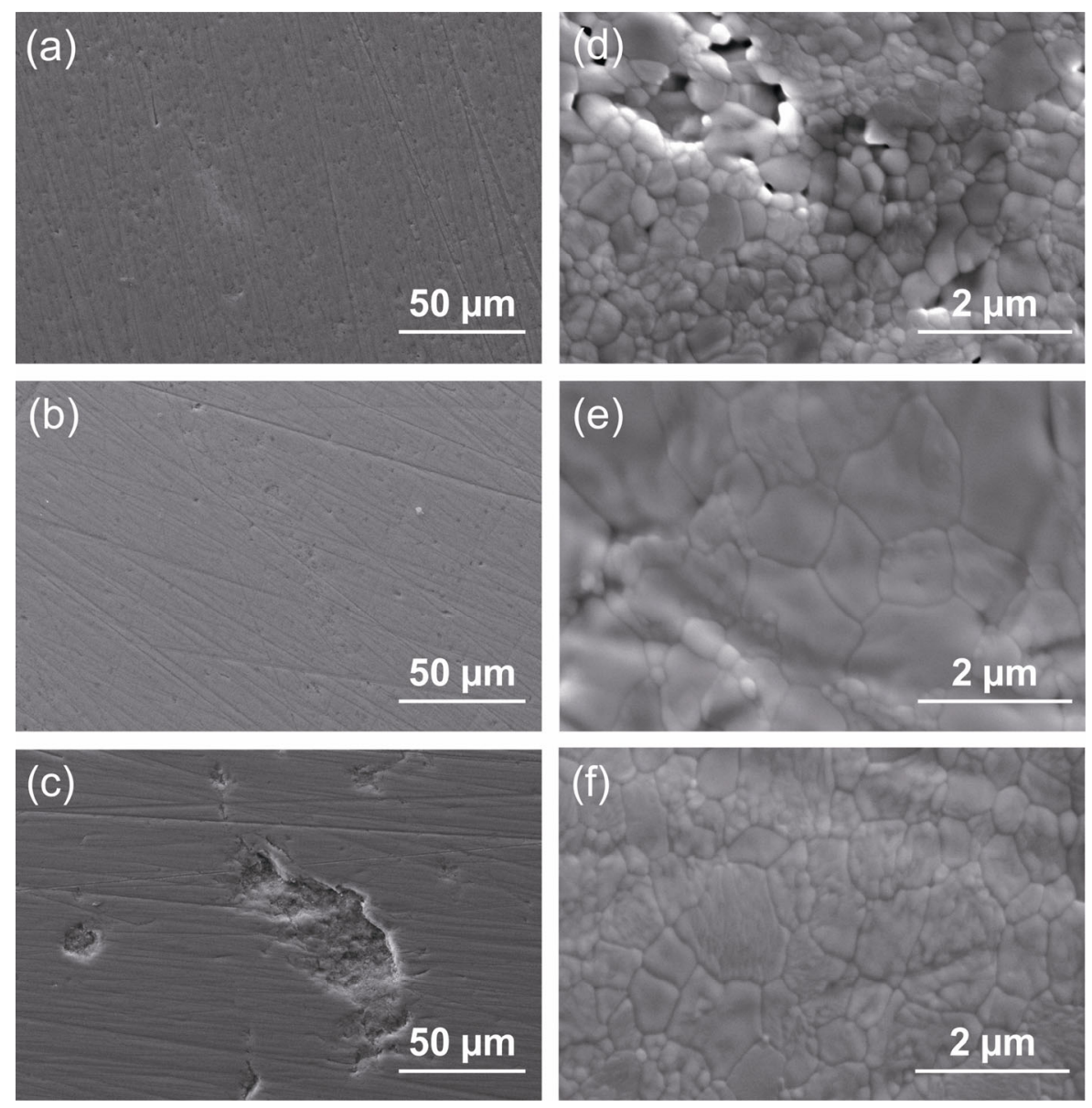

Fig. 7 SEM images showing the surface microstructure of polished YSZ pellets sintered at $1300{ }^{\circ} \mathrm{C}:(\mathrm{a}, \mathrm{d}) \mathrm{TZ}-8 \mathrm{Y}$; (b, e) MELox 8Y; (c, f) YSZ-HT. 
YSZ electrolytes in an actual cell configuration, the electrolyte slurries consisting of the respective YSZ powders were coated onto the pre-sintered anode tubes. Figure 8 shows cross-sectional SEM images of the YSZ electrolyte layers co-sintered with the NiO-YSZ anodes at different temperatures. As can be seen, the densification behavior of the thin-film electrolytes on the anode supports is remarkably different from that of the self-supporting electrolyte pellets. For the thin-film electrolytes, YSZ-HT shows the highest sintering rate with an almost fully densified microstructure at 1250 ${ }^{\circ} \mathrm{C}$. MELox $8 \mathrm{Y}$ and TZ-8Y have a comparable sintering behavior and both the powders achieve full densification at $1300{ }^{\circ} \mathrm{C}$. Although the densification of the YSZ-HT pellets is affected by the random agglomeration of the fine particles, the agglomerates are broken by ball milling during the preparation of the electrolyte slurry. Thus, there is a homogeneous densification of the thin-film YSZ-HT electrolytes. Additionally, as shown in Fig. 9, the shrinkage profile of the pre-sintered anode may be attributed to aiding in the rapid densification of the YSZ-HT electrolyte. Ideally, there should be a close match in the sintering shrinkage of the electrolyte and anode support with a slightly higher shrinkage of the support layer to facilitate the electrolyte densification under compression $[32,45]$. As indicated by Fig. 9, it is likely that the YSZ-HT powder meets this condition better than the other two kinds of powders. The very high shrinkage of the MELox $8 Y$ powder and the very low shrinkage of the TZ-8Y powder both seem to be less favorable for the electrolyte densification below $1300{ }^{\circ} \mathrm{C}$.

To test the gas tightness of the thin-film electrolytes co-sintered at $1250{ }^{\circ} \mathrm{C}$, single cell samples were prepared. A typical cross-section of a reduced cell with the YSZ-HT electrolyte is shown in Fig. 10(a). The electrolyte is dense as expected, although it contains some isolated closed pores. The thickness of the electrolyte is measured to be ca. $12 \mu \mathrm{m}$. Figure 10(b) shows the $I-V$ characteristic curves for the cell at different temperatures. The cell has OCVs of 1.06, 1.07 , and $1.08 \mathrm{~V}$ at 800,750 , and $700{ }^{\circ} \mathrm{C}$, respectively. These OCVs are close to the theoretical values, thus confirming the gas impermeability of the YST-HT electrolyte. The cell delivers maximum power densities of $0.4,0.32$, and $0.24 \mathrm{~W} / \mathrm{cm}^{2}$ at 800,750 , and $700{ }^{\circ} \mathrm{C}$,
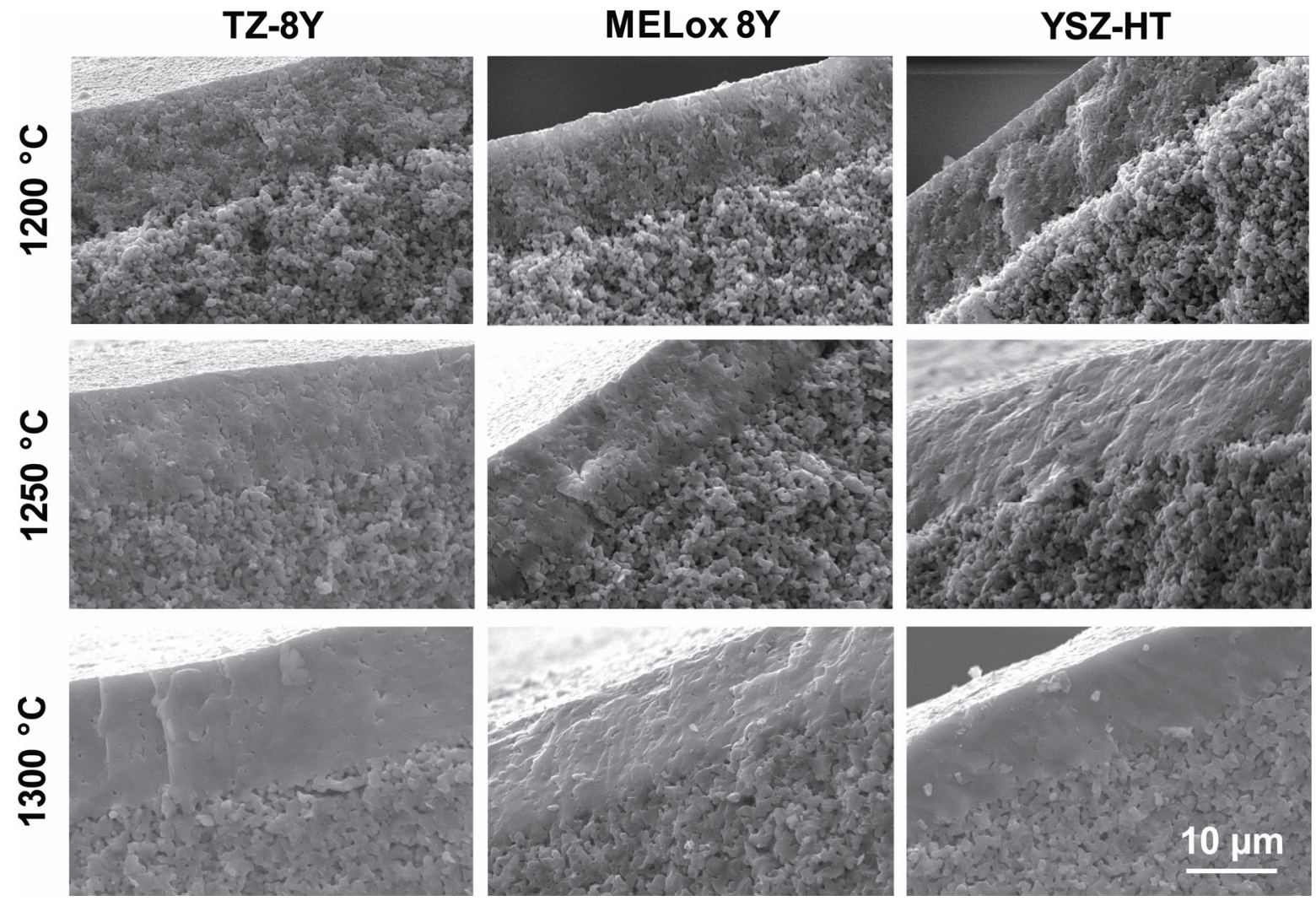

Fig. 8 Cross-sectional SEM images of the thin-film YSZ electrolytes co-sintered with NiO-YSZ anode supports at different temperatures. The scale bar applies to all the images. 


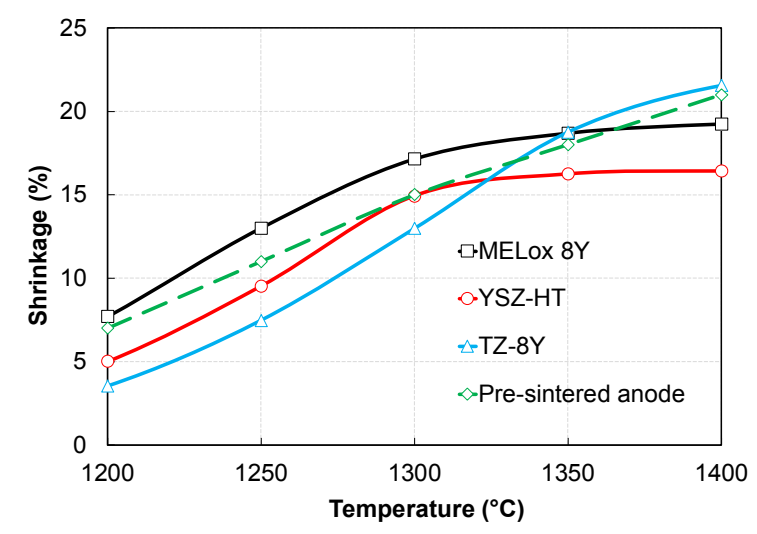

Fig. 9 Comparison of the sintering shrinkage between the pre-sintered anode and YSZ powders.

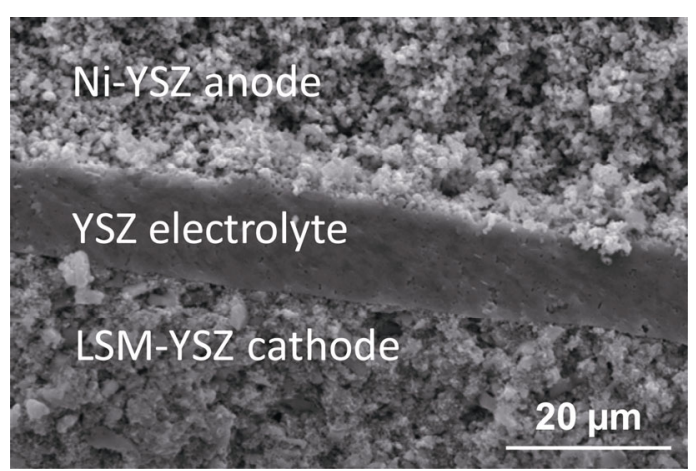

(a)

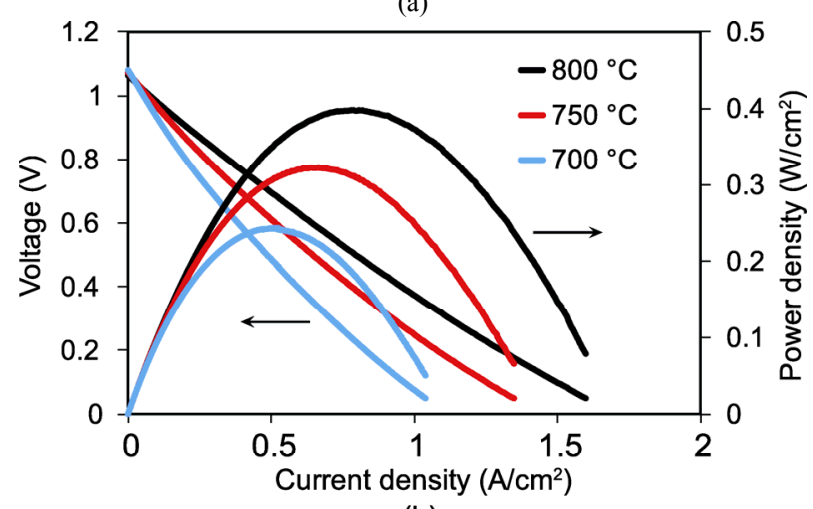

(b)

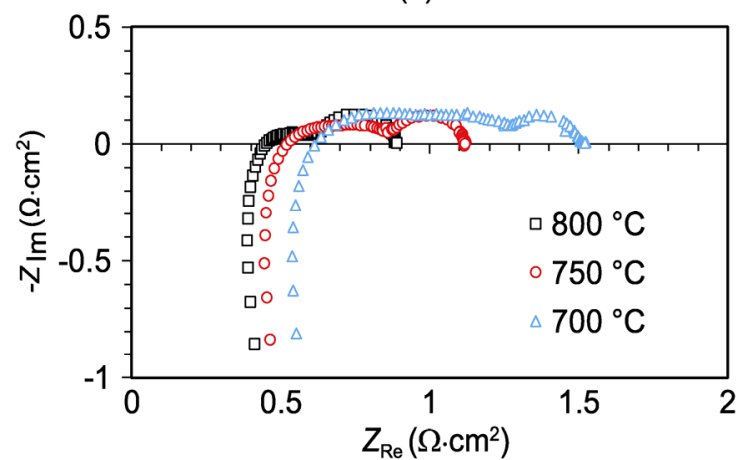

(c)

Fig. 10 Electrochemical testing of the single cell containing YSZ-HT electrolyte co-sintered at $1250{ }^{\circ} \mathrm{C}$ : (a) fractured cell cross-section; (b) $I-V$ curves; (c) impedance spectra. respectively. On the other hand, the TZ-8Y and MELox $8 \mathrm{Y}$ electrolytes co-sintered at $1250{ }^{\circ} \mathrm{C}$ are not dense enough to prevent the gas crossover. As a result, no OCV or electrochemical performance could be recorded for the cells containing these electrolytes. Figure 10(c) shows impedance spectra for the single cell with the YSZ-HT electrolyte under OCV conditions. The total cell resistances are $0.89,1.12$, and $1.52 \Omega \cdot \mathrm{cm}^{2}$ at 800,750 , and $700{ }^{\circ} \mathrm{C}$, respectively. The contribution of the ohmic resistance, as given by the high-frequency (left) intercept on the real axis, to the total cell resistance is found to be relatively high because of the current collection losses. With a better current collection method and microstructure optimization of the electrodes including the addition of an anode functional layer [46], improved cell performance could be achieved.

\section{Conclusions}

The densification behavior of three different kinds of commercial $8 \mathrm{~mol} \%$ YSZ electrolyte powders was investigated by forming them into disc-shaped pellets as well as thin-film layers on top of the NiO-YSZ anode supports. For the densification of the self-supporting pellets, MELox $8 \mathrm{Y}$ exhibited the highest densification at lower sintering temperatures. Considering a relative density of $\geqslant 95 \%$ to be essential for a gas-tight electrolyte, the MELox 8Y powder could be densified at $1300{ }^{\circ} \mathrm{C}$. In comparison, a sintering temperature of $1350{ }^{\circ} \mathrm{C}$ was required for the full densification of TZ$8 \mathrm{Y}$ and YSZ-HT powders. The densification behavior of the thin-film YSZ electrolytes on the anode supports was remarkably different from that of the YSZ pellets. For the thin films, YSZ-HT showed the highest sintering rate with a sufficiently dense microstructure at $1250{ }^{\circ} \mathrm{C}$. The gas tightness of the YSZ-HT electrolyte cosintered at $1250{ }^{\circ} \mathrm{C}$ was also confirmed by the single-cell OCV values. On the other hand, the MELox $8 \mathrm{Y}$ and $\mathrm{TZ}-8 \mathrm{Y}$ powders achieved full densification only at a co-sintering temperature of $1300{ }^{\circ} \mathrm{C}$. The following conclusions were made from our study:

(1) Although the fine YSZ particles tend to have better sintering properties owing to their higher surface energy, additional factors such as particle size distribution and post-processing of the powders play a significant role in determining the sintering rate and densification behavior of the YSZ pellets. 
(2) The post-processing of the YSZ powders such as spray drying helps to achieve better compaction during dry pressing and thus uniformly sintered pellets. Without post-processing, the agglomeration of fine YSZ particles could lead to an inhomogeneous sintered microstructure containing defects.

(3) For the thin-film YSZ electrolytes, matching of the shrinkage profiles between the YSZ powders and the support layer plays an important role in addition to the powder properties. With a careful selection of the YSZ powders and by matching the shrinkage profiles of the electrolyte and support, a considerable reduction in the electrolyte co-sintering temperature can be achieved.

\section{Acknowledgements}

This work was partially supported by National Aeronautics and Space Administration (NASA) through Contract No. NNX15CC12C. The authors are grateful to Professor Min-Fang Han at Tsinghua University for providing the YSZ-HT powder and MEL Chemicals for providing the MELox 8Y powder. The authors would like to thank Professor Kevin Huang and Mr. Tianrang Yang at University of South Carolina and Dr. Wenxia Li at Zircoa, Inc. for their insightful discussions and help. The SEM micrographs were obtained at the SEM lab of the Liquid Crystal Institute (LCI) Characterization Facility, Kent State University.

\section{References}

[1] Wachsman ED, Lee KT. Lowering the temperature of solid oxide fuel cells. Science 2011, 334: 935-939.

[2] Steele BCH, Heinzel A. Materials for fuel-cell technologies. Nature 2001, 414: 345-352.

[3] Singhal SC. Advances in solid oxide fuel cell technology. Solid State Ionics 2000, 135: 305-313.

[4] Fergus JW. Electrolytes for solid oxide fuel cells. J Power Sources 2006, 162: 30-40.

[5] Ivers-Tiffée E, Weber A, Herbstritt D. Materials and technologies for SOFC-components. J Eur Ceram Soc 2001, 21: 1805-1811.

[6] Chevalier J, Gremillard L, Virkar AV, et al. The tetragonalmonoclinic transformation in zirconia: Lessons learned and future trends. J Am Ceram Soc 2009, 92: 1901-1920.

[7] Panthi D, Tsutsumi A. A novel multistep dip-coating method for the fabrication of anode-supported microtubular solid oxide fuel cells. J Solid State Electrochem 2014, 18:
$1899-1905$.

[8] Hedayat N, Panthi D, Du Y. Fabrication of tubular solid oxide fuel cells by solvent-assisted lamination and co-firing a rolled multilayer tape cast. Int J Appl Ceram Tec 2018, 15: 307-314.

[9] Hedayat N, Du Y, Ilkhani H. Review on fabrication techniques for porous electrodes of solid oxide fuel cells by sacrificial template methods. Renew Sust Energ Rev 2017, 77: 1221-1239.

[10] Menzler NH, Tietz F, Uhlenbruck S, et al. Materials and manufacturing technologies for solid oxide fuel cells. $J$ Mater Sci 2010, 45: 3109-3135.

[11] Han M, Tang X, Yin H, et al. Fabrication, microstructure and properties of a YSZ electrolyte for SOFCs. J Power Sources 2007, 165: 757-763.

[12] Panthi D, Choi B, Du Y, et al. Lowering the co-sintering temperature of cathode-electrolyte bilayers for microtubular solid oxide fuel cells. Ceram Int 2017, 43: 10698 10707.

[13] Marrero JC, Ribeiro NFP, Malfatti CF, et al. Characterization of yttria-stabilized zirconia films deposited by dip-coating on $\mathrm{La}_{0.7} \mathrm{Sr}_{0.3} \mathrm{MnO}_{3}$ substrate: Influence of synthesis parameters. $J A d v$ Ceram 2013, 2: 55-62.

[14] Hedayat N, Panthi D, Du Y. Fabrication of anodesupported microtubular solid oxide fuel cells by sequential dip-coating and reduced sintering steps. Electrochim Acta 2017, 258: 694-702.

[15] Yoon KJ, Huang W, Ye G, et al. Electrochemical performance of solid oxide fuel cells manufactured by single step co-firing process. J Electrochem Soc 2007, 154: B389-B395.

[16] Dai H, Chen H, He S, et al. Improving solid oxide fuel cell performance by a single-step co-firing process. $J$ Power Sources 2015, 286: 427-430.

[17] Panthi D, Choi B, Tsutsumi A. Performance improvement and redox cycling of a micro-tubular solid oxide fuel cell with a porous zirconia support. Int $J$ Hydrogen Energ 2015, 40: 10588-10595.

[18] Panthi D, Choi B, Tsutsumi A. Direct methane operation of a micro-tubular solid oxide fuel cell with a porous zirconia support. J Solid State Electrochem 2017, 21: 255-262.

[19] Zhao K, Kim B-H, Du Y, et al. Ceria catalyst for inert-substrate-supported tubular solid oxide fuel cells running on methane fuel. J Power Sources 2016, 314: $10-17$.

[20] Tucker MC. Progress in metal-supported solid oxide fuel cells: A review. J Power Sources 2010, 195: 4570-4582.

[21] Han Z, Yang Z, Han M. Fabrication of metal-supported tubular solid oxide fuel cell by phase-inversion method and in situ reduction. Int $J$ Hydrogen Energ 2016, 41: 10935-10941.

[22] Cho HJ, Kim KJ, Park YM, et al. Flexible solid oxide fuel cells supported on thin and porous metal. Int J Hydrogen Energ 2016, 41: 9577-9584.

[23] Zhu Q, Fan B. Low temperature sintering of 8YSZ 
electrolyte film for intermediate temperature solid oxide fuel cells. Solid State Ionics 2005, 176: 889-894.

[24] Zhao H, Li X, Ju F, et al. Effects of particle size of 8 $\mathrm{mol} \% \mathrm{Y}_{2} \mathrm{O}_{3}$ stabilized $\mathrm{ZrO}_{2}$ (YSZ) and additive $\mathrm{Ta}_{2} \mathrm{O}_{5}$ on the phase composition and the microstructure of sintered YSZ electrolyte. J Mater Process Tech 2008, 200: 199204.

[25] Lewis GS, Atkinson A, Steele BCH. Cobalt additive for lowering the sintering temperature of yttria-stabilized zirconia. J Mater Sci Lett 2001, 20: 1155-1157.

[26] Flegler AJ, Burye TE, Yang Q, et al. Cubic yttria stabilized zirconia sintering additive impacts: A comparative study. Ceram Int 2014, 40: 16323-16335.

[27] Gao Z, Kennouche D, Barnett SA. Reduced-temperature firing of solid oxide fuel cells with zirconia/ceria bi-layer electrolytes. J Power Sources 2014, 260: 259-263.

[28] Zhou M, Ge L, Chen H, et al. Effect of transition metal oxides doping on $\mathrm{Ce}_{0.9} \mathrm{Sm}_{0.05} \mathrm{Nd}_{0.05} \mathrm{O}_{1.95}$ solid electrolyte materials. J Adv Ceram 2012, 1: 150-156.

[29] Rajeswari K, Suresh MB, Chakravarty D, et al. Effect of nano-grain size on the ionic conductivity of spark plasma sintered 8YSZ electrolyte. Int J Hydrogen Energ 2012, 37 : 511-517.

[30] Munir ZA, Quach DV, Ohyanagi M. Electric current activation of sintering: A review of the pulsed electric current sintering process. J Am Ceram Soc 2011, 94: 1-19.

[31] Gaudon M, Menzler NH, Djurado E, et al. YSZ electrolyte of anode-supported SOFCs prepared from sub micron YSZ powders. J Mater Sci 2005, 40: 3735-3743.

[32] Leng YJ, Chan SH, Khor KA, et al. Effect of characteristics of $\mathrm{Y}_{2} \mathrm{O}_{3} / \mathrm{ZrO}_{2}$ powders on fabrication of anode-supported solid oxide fuel cells. J Power Sources 2003, 117: 26-34.

[33] Yamaguchi T, Suzuki T, Shimizu S, et al. Examination of wet coating and co-sintering technologies for microSOFCs fabrication. J Membrane Sci 2007, 300: 45-50.

[34] Suzuki T, Yamaguchi T, Hamamoto $\mathrm{K}$, et al. Low temperature densification process of solid-oxide fuel cell electrolyte controlled by anode support shrinkage. RSC Adv 2011, 1: 911-916.

[35] Panthi D, Tsutsumi A. Micro-tubular solid oxide fuel cell based on a porous yttria-stabilized zirconia support. Sci Rep 2014, 4: 5754.

[36] Courtin E, Boy P, Piquero T, et al. A composite sol-gel process to prepare a YSZ electrolyte for Solid Oxide Fuel Cells. J Power Sources 2012, 206: 77-83.
[37] Muccillo R, Muccillo ENS. An experimental setup for shrinkage evaluation during electric field-assisted flash sintering: Application to yttria-stabilized zirconia. J Eur Ceram Soc 2013, 33: 515-520.

[38] Freitas C, Vitorino N, Abrantes JCC, et al. Burnout effects on cellular ceramics obtained from gelatine gelcasted emulsified suspensions. J Eur Ceram Soc 2015, 35: 971-979.

[39] Yu PC, Li QF, Fuh JYH, et al. Two-stage sintering of nano-sized yttria stabilized zirconia process by powder injection moulding. J Mater Process Tech 2007, 192-193: 312-318.

[40] Gaudon M, Djurado E, Menzler NH. Morphology and sintering behaviour of yttria stabilised zirconia (8-YSZ) powders synthesised by spray pyrolysis. Ceram Int 2004, 30: $2295-2303$.

[41] Walker WJ, Reed JS, Verma SK. Influence of slurry parameters on the characteristics of spray-dried granules. $J$ Am Ceram Soc 1999, 82: 1711-1719.

[42] Ji C, Shapiro IP, Xiao P. Fabrication of yttria-stabilizedzirconia coatings using electrophoretic deposition: Effects of agglomerate size distribution on particle packing. J Eur Ceram Soc 2009, 29: 3167-3175.

[43] Pandey AK, Biswas K. Effect of agglomeration and calcination temperature on the mechanical properties of yttria stabilized zirconia (YSZ). Ceram Int 2014, 40: 14111-14117.

[44] Loghman-Estarki MR, Pourbafrany M, Razavi RS, et al. Preparation of nanostructured YSZ granules by the spray drying method. Ceram Int 2014, 40: 3721-3729.

[45] De Souza S, Visco SJ, De Jonghe LC. Reduced-temperature solid oxide fuel cell based on YSZ thin-film electrolyte. $J$ Electrochem Soc 1997, 144: L35-L37.

[46] Yoon D, Lee J-J, Park H-G, et al. NiO/YSZ-YSZ nanocomposite functional layer for high performance solid oxide fuel cell anodes. $J$ Electrochem Soc 2010, 157: B455-B462.

Open Access The articles published in this journal are distributed under the terms of the Creative Commons Attribution 4.0 International License (http://creativecommons.org/licenses/ by/4.0/), which permits unrestricted use, distribution, and reproduction in any medium, provided you give appropriate credit to the original author(s) and the source, provide a link to the Creative Commons license, and indicate if changes were made. 